\title{
Using Illustrations to Depict Preservice Science Teachers' Self-Efficacy: A Case Study
}

\author{
Robert Del Greco \\ Assoc. Prof., Ed.D Robert Morris University, USA, delgreco@rmu.edu \\ Carianne Bernadowski \\ Ph.d., Robert Morris University, USA, bernadowski@rmu.edu \\ Susan Parker \\ Ph.d., Robert Morris University, USA, parker@rmu.edu
}

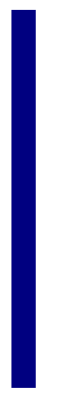

This qualitative case study conducted at a small private university in the U.S. found that preservice teacher self-efficacy increased over the course of four semesters when taught inquiry-based instruction from a Social Constructivist Theoretical framework. This study utilized A Draw a Science Teacher Test Checklist (DASTT-C) created by Thomas, Pederson, and Finson (2001) and required students to draw themselves both at the beginning and end of the semester. Additionally, three themes were found in the reflections of the students which included: teacher as facilitator, students as teachers, learning through inquiry. Based on these findings, it is clear that preservice teachers' attitudes and beliefs can be changed based on university instructional and course design.

Keywords: list (5-7) preservice science teachers, teachers' self-efficacy, inquiry-based instruction, constructivism, case study, teacher

\section{INTRODUCTION}

Since the launch of the Russian satellite, Sputnik, in 1957, science education in America has been the subject of frequent, if not constant reevaluation, revamping and remodeling. It came under scrutiny with the historic Russian satellite launch sixty years ago, as the U.S. government, military and scientific community, as well as the American public, at large, were caught off guard by this Soviet technological achievement. In an effort to catch up to the Russians the Eisenhower administration, initially, and then the Kennedy administration, poured millions of dollars into both scientific research and education as the U.S. jumped, headlong, into the "space race."

Hence, Sputnik contributed directly to the birth of the National Aeronautics and Space Administration (NASA) and the National Defense Education Act, which provided low interest loans for college tuition as incentive to attract students majoring in math or

Citation: Greco, R. D., Bernadowski, C., \& Parker, S. (2018). Using Illustrations to Depict Preservice Science Teachers' Self-Efficacy: A Case Study. International Journal of Instruction, 11(2), 75-88. https://doi.org/10.12973/iji.2018.1126a 
science. With this increase in government spending, and the new emphasis on science and technology in American schools, it can be said that the U. S. response to the Sputnik launch inspired a generation of engineers and scientists. This heightened interest in science and technology, and the preparatory programs leading to careers in engineering, research, and related fields, led to the reexamination of the teaching of science and the subsequent "wave of new curricular ideas: science literacy, scientific literacy, the nature of science (NOS), and inquiry, to name a few" (Bullock and Astor, pp.62, 63). Within the last decade we can add to the mix the STEM (Science, Technology, Engineering and Mathematics) movement, and more recently the maker movement and maker pedagogy. It is remarkable to observe the full circle that science education appears to have taken over those 60 years since the Sputnik launch and the priority that the nation has placed on science education.

Going hand in hand with these curricular changes in science education are, of course, the examination and realignment of preparatory programs, that is, those programs preparing future teachers, both secondary science teachers, as well as elementary teachers who are responsible for teaching all disciplines, mathematics reading and language arts, science and social studies. Moreover, the concept of teaching self-efficacy lies at the heart of preservice teachers' performance and how this plays into their ability to be successful in the classroom. By using inquiry-based instructional strategies with preservice teachers, the researchers were able to help students make those connections. This research study focused on the impact of teaching inquiry-based science methods on the self-efficacy of preservice teachers, as well as preservice teachers' perceptions of students and their role in the science classroom.

\section{REVIEW OF THE LITERATURE}

\section{Science Education in the U.S.}

The initial surge of students pursuing careers in the various areas of engineering, including aerospace engineering, technology, and research, as well as those pursuing teaching degrees in the sciences, continued through the 1960s and 1970s, before waning in the 1980s. A sense of complacence set in as the U.S. continued to make strides on the technology front, establishing itself as a world leader in that domain, while at the same time the excitement in the U.S. space exploration program began to fade shortly after the Apollo 11 space mission successfully landed two humans on the moon in 1969. The nation's regard for NASA and space exploration then went from mild disinterest to a complete lack of confidence after the disastrous 1986 launching of the space shuttle Challenger.

In addition, the incentives drawing flocks of college students into engineering and the sciences in the 1960s and 1970s resulted in a glut of degree carrying scientists and engineers which were, at first, easily absorbed into the job market. However, just beyond the 1970s, the economic recession of the early1980s made these fields less attractive as the college grads holding those degrees were facing a job market with few opportunities. Likewise, in the teaching profession, as school enrollments which had peaked in the 1950s and 1960s, began to drop in subsequent decades, school closings, building consolidations, and teacher furloughs became commonplace, and teacher 
education programs realized a drop in enrollment. It appeared that fewer and fewer young people were having an interest in becoming teachers, and even fewer demonstrated a desire to become science teachers, in part because of the lack of job opportunities in general, but also, in many cases, those high school grads with a high math or science aptitude, and who may have been interested in a possible career in education, found that their earning power was much greater working in business or industry versus a career in public education. With this said, teacher education programs, during those years reflected the survival mode of the times.

\section{Perceptions and Preconceived Notions}

Teaching science generally follows one of two approaches, traditional or constructivist. When utilizing a traditional approach, it typically entails the teacher delivering scientific facts as learners passively absorb the information. A constructivist approach places the emphasis on the learner, who must be actively engaged in the inquiry, discovery and learning process. Constructivism is often viewed as an optimal fit because it relates to the hands-on nature of science inquiry and also aligns excellently with developmentally appropriate practices (DAP), which are a cornerstone of best practice early childhood curricula.

The National Association Education of Young Children (NAEYC) guidelines for developmentally appropriate practices (DAP) have achieved an undisputed place in early childhood education (Kim, 2011), and are considered a key component in any early childhood education program. It is outside the scope of this paper to provide an extensive description of DAP. However, DAP is a broad over-arching concept that provides a framework for teaching children from birth to age eight. It encompasses three core considerations: knowing about child development and learning, knowing what is individually appropriate, and knowing what is culturally appropriate. Teachers who are familiar with DAP are able to meet a child where he or she is developmentally, and move them forward with scaffolding, modeling, and active learning strategies. Additionally, using DAP lends to keeping children actively engaged in their own learning, an important element of Constructivist Learning Theory. And unlike middle and secondary education, which focuses on academic subject areas, early childhood education has for decades emphasized learning through play, active learning, theoretically aligning itself in many ways with constructivism. Therefore, one might surmise that pre-service early childhood teachers may have more constructivist than traditional views of teaching science from mere exposure in university classrooms.

However, once beliefs are in place they are often difficult to change (Smith, 1997; Tschannen-Moran, et. al., 1998). Despite the infusion of innovative, research-based teaching techniques into teacher training programs over the past 50 years, many aspects of the old adage, "teachers teach as they were taught," still ring true. This commentary specific to the uniqueness of the teaching profession is well-defined by Grierson who notes that "unlike those entering other professions, teacher candidates enter as insiders whose biographical educational experiences create firm beliefs about teaching that can be expected to be both incomplete and resistant to change." (p.4) [also Pajares, 1992] 
Underscoring this point further, in their analysis of elementary preservice teachers' resistance to learning and teaching through inquiry, Spector, Burkett, and Leard (2007) observed, "Many of these people cling to their own personal experience as students in elementary schools to determine what will or will not work for them as elementary teachers" (p. 185). Spector, et al. (2007) further note that each individual's cognitive framework is composed of many mental models accumulated during one's lifetime and is, therefore, idiosyncratic. With that said, teacher educators must acknowledge that "resistance to learning science and science teaching through inquiry, is common among preservice students in classes teaching methods of science for the elementary grades" ( $\mathrm{p}$. 186). However, it is possible to shift individual's self-image paradigms from one of traditional teaching of science to a more inquiry-based, constructivist approach (Go \& Kang, 2015). This shift is more easily accomplished before teachers become entrenched in their own teaching methods, and hold mental maps of teaching. Therefore, it is important to examine the beliefs of pre-service teachers regarding how to teach science, as beliefs influence teaching behaviors (Markic \& Eilks, 2008), inform the roles of teachers and learners in science education, and provide a foundation for developing materials (Sadhana, et al., 2012; Thomas, Pederson, \& Finson, 2001).

\section{Reflection in Teaching}

Employing reflection and reflective practice is critical to teaching. It is a deliberate, willful process for learning. In linking together the concepts of pre-conceived notions and mental models to the power of reflective practice, Peter Senge, in his work, The Fifth Discipline, The Art and Practice of the Learning Organization, (1990), discusses the discipline of managing mental models. He defines mental models as those images, assumptions, and stories that we carry in our heads. Further, Senge states that these mental models, or generalizations, shape how we act. Understanding this concept is crucial if one is to employ reflection as a meaningful teaching and learning practice. Senge suggests that a critical first step in implementing reflection is to recognize the "importance of making one's views open to influence; and the problem of confusing our mental models with reality" (p. 248).

Senge, Kleiner, Roberts, Ross and Smith (1994) described reflection as "slowing down our thinking processes to become more aware of how we form our mental models" (p.237). The challenge associated with the implementation of reflective practice with preservice teachers lies in their lack of familiarity, or at the very least, limited exposure to the practice of true reflection. Many students can graduate from high school never having had a teacher or teachers who've utilized reflection as a part of their teaching repertoire, and it can be taken a step further, recognizing that many college students, both education majors and others, have not been challenged to engage in reflection until reaching their teaching methods courses, pre-student teaching, and student teaching, or in the case of other disciplines, their clinical experiences, internships, or practica. So, the concept and practice of reflection can be a new adventure for many preservice teachers, and in reality, it can be said that many veteran, in-service teachers, rarely engage in serious reflection. 
It is accepted that reflection is an essential teaching practice, and in fact, reflection is crucial to successful teaching. Myers (2012) describes teacher reflection as "the ability to persistently and carefully consider what and how we are teaching, and to reflect on our actions as teachers determine what works best for our students" (p. 1). It is through that self-reflection that teaching realizations occurs. Myers continues that, "while definitions vary, most educators agree that thinking beyond superficial elements of one's experience to explore it in greater depth is what enables deep and meaningful learning" (p. 1). Moreover, it is the process of reflecting upon and truly analyzing one's experiences and actions that enables beginning teachers to draw connections between theory and practice, and to develop broader and more sophisticated mental models, or conceptions, of teaching and learning. Hence, encouraging reflection and cultivating reflective practitioners has become one of the cornerstones of quality teacher education programs.

\section{Inquiry-based Instruction}

As noted earlier, science education has experienced a rebirth over the past two decades, in part due to reports of U.S. student performance slipping on the global stage, when compared to students of other industrialized nations, particularly in the areas of math and science. Today, STEM (science, technology, engineering and mathematics), as well as STEAM (science, technology, engineering, arts, and mathematics) education have become an accepted part of most K-12 curricula, with inquiry-based learning being an integral part of these STEM and STEAM initiatives. Actually, inquiry-based learning has become, in recent years, an important teaching strategy tapped by teachers across many disciplines, with science education at the forefront.

According to Manz (2015), in recent years, there has been "increasing attention given across disciplines to considering how the work of K-12 student should align with the work of practitioners in relevant fields" (p. 89). In fact, as early as 1996 the National Research Council (NRC) declared that inquiry instruction be recognized as a cornerstone to the science teaching standards, and within the context of the teaching standards inquiry is defined as a pedagogical method combining higher order questioning with student-centered discussion and discovery of central concepts through laboratory activities (NRC, 1996).

Supporting this concept, Damnjanovic (1999) states that a central aim of inquiry teaching is to develop students' intellectual autonomy. To clarify this point, in traditionally taught classrooms, students regard teachers as experts, holding the key to knowledge, providing answers to all questions. In essence, students regard teachers accountable for their knowledge base. Whereas, in inquiry-based instruction, students learn to construct their own understanding and they assume responsibility for establishing their own knowledge base. Following this scenario, the classroom teacher's role shifts from that of resident expert to facilitator.

To further demonstrate the concept of science education and inquiry aligning with the work of practitioners in the field, i.e. scientists, Moore (1993) noted that science has been described as both a knowledge of the natural world and a procedure used to obtain that knowledge, thus, inquiry teaching models science. In an inquiry-based learning 
environment, students are encouraged to experience the processes of science. Scientific methods, or processes, include making an observation, formulating questions, developing a hypothesis, conducting an experiment, analyzing data, and drawing conclusions.

Reflecting these processes, the National Science Education Standards (NRC, 2000) advocate for inquiry as a key element of science instruction. The Standards identify five essential elements for inquiry. Students should

- $\quad$ ask scientifically oriented questions,

- use evidence,

- formulate explanations,

- compare and evaluate explanations,

- $\quad$ and communicate and justify their explanations (NRC 2000, p. 25)

To summarize, Meyer (2012) states, "students should be involved in making empirically based arguments, which is at the heart of what scientists do" (p. 39), and, according to Melville, et al. (2008) "an inquiry-based curriculum seeks to actively engage students in their own learning so they develop strategies for generating and solving problems and a capacity to pursue those strategies to produce data" (p.78). Once that data has been analyzed, students then draw conclusions and communicate their findings.

So, with the argument made on behalf of inquiry-based instruction, the dilemma lies with its implementation, not only by veteran, in-service teachers, but more so, by preservice teachers who, not unlike their veteran counterparts, come to the table with wide and varied experiential backgrounds and understandings of inquiry, and an even wider range in regards to their level of comfort in implementing inquiry-based practices into their teaching of science. The challenge for preservice teachers is augmented by the fact that along with incorporating inquiry into their instructional repertoire, preservice teaching are also working to develop a deeper understanding of the science content that they are charged with delivering to their students.

\section{Preservice Teachers' Self-efficacy}

Grounded in Bandura's Social Cognitive Theory (1977, 1986, 1997), teacher efficacy became known as a major theory in teacher education dating back to the 1980s. Bandura posited that self-efficacy beliefs motivated people toward specific actions in all aspects of their lives. Stated simply, according to Bandura (1977), "People fear and tend to avoid threatening situations they believe exceed their coping skills, whereas they get involved in activities and behave assuredly when they judge themselves capable of handling situations that would otherwise be intimidating" (p.194).

Based on this premise, Bandura identified two dimensions of self-efficacy, those being personal self-efficacy and outcome expectancy. Bandura defined these constructs, describing personal self-efficacy as the "belief in one's capabilities to organize and execute the courses of action required to produce given attainments, whereas outcomes expectancy is a judgement of the likely consequence such performances will produce" (Bandura, 1977, p. 194). 
When applied to teaching, personal self-efficacy is generally regarded as Personal Teaching Efficacy (PTE). Cantrel, Young, and Moore (2003) describe teachers with a high level of PTE as having confidence that they have adequate training or experience to develop strategies for overcoming obstacles to student learning. The second dimension identified by Bandura, outcome expectancy, claims that an intention to undertake some action is based on the expected success of that action. When applied to teaching, this factor is frequently referred to as General Teaching Efficacy (GTE). To clarify further, this concept refers to an individual teacher's perception of his or her own capabilities extending beyond, to their perception of teachers in general (Cantrel, et al., 2003). For example, a teacher with a low GTE may feel that teachers have little impact on student motivation and student achievement, because they have no control over students' home environment. According to Gibson and Dembo (1984), when PTE and GTE are applied to teaching, "...teachers who believe student learning can be influenced by effective teaching (GTE) and who also have confidence in their on teaching abilities (PTE) should persist longer, provide a great academic focus in the classroom, and exhibit different types of feedback than teachers who have lower expectations concerning their ability to influence student learning" (p.570).

Bandura (1997) defined self-efficacy as a situation-specific concept and professes that science teaching efficacy "is of particular concern, given the increasing importance of scientific literacy and competency in the technological transformations occurring in society" (p. 242). Further, when applying this notion to elementary science teaching, this principle may shed light on elementary teachers' regard for the teaching of science. As we know elementary teachers are often responsible for the teaching of all basic subjects, reading and language arts, mathematics, science and social studies, and their regard for, as well as their effectiveness in the teaching of these subjects, may vary from teacher to teacher, based on his/her personal preferences, which are, of course, rooted in their sense of teaching efficacy.

\section{COURSE DESIGN}

The course places emphasis on theory and practical knowledge necessary for planning, implementing, and assessing a science and health program in a contemporary elementary school. Students are introduced to a variety of approaches and instructional materials for effectively facilitating the learning of content and skills drawn from science, physical education and health, and for integrating learning with other areas of the elementary curriculum. The course met for 15 weeks and had field requirements built into the course curriculum.

The course is required for all early childhood education majors, and occurs in the spring of junior year, the semester prior to pre-student teaching. At the conclusion of the course, pre-service teachers should be able to demonstrate an understanding of the nature of science, health, and physical education concepts as they relate to science teaching and learning. Additionally, they will have demonstrated appropriate science teaching behaviors (including, but not limited to, lab safety, problem solving, and concept development). They will develop and present science lessons that showcase his/her knowledge, attitudes and skills for inquiry teaching and learning. Table 1 shows the main course activities and the types of instructional delivery utilized. 
A unique aspect of science education in ECED 4020 is a focus on how to implement maker-centered learning in the early childhood science classroom. The maker movement centers on learning through hands-on making, creating, designing, trial and error and innovation (Peppler \& Bender, 2013). According to Dougherty (2013), the maker movement is growing in popularity, with maker spaces and Maker Fairs popping up all over the United States and the world. Constructivism, DAP, and Maker centered learning are three distinct frameworks. However, they have many commonalities in their approaches to teaching and learning, and all intersect in some way with science education.

Table 1

Content and course activities

\begin{tabular}{ll}
\hline Course Activity/Explanation & Instruction/Delivery Method \\
\hline Initial "Draw A Science Teacher" & Instructor Directed \\
$\begin{array}{l}\text { Junior Achievement - Participate complete a brief reflection. } \\
\text { Quick Writes -Timed 12 minute written response to a relevant question, } \\
\text { reading, activity }\end{array}$ & Field Work \\
$\begin{array}{l}\text { MakeShop Project- Cooperative venture with the Children's Museum and a } \\
\text { Primary Center }\end{array}$ & Knowledge \\
$\begin{array}{l}\text { Science Fair - Develop, plan, teach an inquiry science lesson in grades K-4 } \\
\begin{array}{l}\text { Discrepant Event - Research, plan, present a discrepant event; teaching } \\
\text { strategy provided }\end{array}\end{array}$ & $\begin{array}{l}\text { Field Work, implement lesson } \\
\text { peeate, implement lesson for }\end{array}$ \\
\hline
\end{tabular}
rovided

\section{METHOD}

A qualitative case study design was used for this study. Case study methodology was most applicable because the researchers examined a science methods course offered to preservice early childhood majors. Participants were asked to draw themselves as science teachers before the class began and at the conclusion of the course. Sixteen weeks passed between the first and second drawing. That is, the self-images of preservices teachers were the primary focus of investigation. Case study design was facilitated because it examines an individual case within a real life context or setting (Yin, 2009). Moreover, Baxter and Jack (2008) describe a case study design as one that seeks to "explain the presumed causal links in real-life interventions that are too complex for the survey or experimental strategies" (p.547). Investigating why preservice drew themselves as such was much more complex than could be answered through quantitative analysis. That is, the perceptions of preservice teachers were mined by examining their illustrations which would provide detailed information about their perceptions as opposed to a survey. The main research question examined in this study was: How do preservice teachers perceive themselves before and after instruction in inquiry-based instructional techniques in science?

\section{Participants}

Eighty preservice teachers enrolled in a science methods course at a small private university in Pennsylvania in the United States were utilized for this study. All participants were undergraduate students seeking initial teacher certification and their Bachelors of Science degree and classified as juniors. The semester students take the science methods course is the same semester they are enrolled in their prestudent teaching placement at a local school district where they spend two days in a classroom 
setting with a cooperating teacher and a university supervisor. They meet with the course instructor once a week for three hours totalling 57 hours of instructional time. Data was collected over four semesters from Fall of 2014 until Fall of 2017.

\section{Data Collection}

Participants were asked to report their self-image by illustrating their own science classrooms and themselves in that context both before and after taking a science methods course. More specifically, A Draw a Science Teacher Test Checklist (DASTTC) created by Thomas, Pederson, and Finson (2001) served as the instrument, and interrater reliability was implemented with four raters using a rubric categorized in three domains; teacher, students and environment. The teacher portion of the rubric asks the rater to examine the teacher in relation to the activity and the position in the illustration. Next, the students are examined by the activity and position that is portrayed in the illustration. Finally, the environment portrayed in the illustration is examined. The interrater reliability, the percent agreement between raters, was eighty percent between the four raters utilized for this study.

Additionally, reflective paragraphs of the several preservice teachers were examined at the conclusion of the course. While taking the science methods course, preservice teachers engaged in a 16 week, four hours per week course along with two days a week (8 hours a day) in an early childhood classroom (k-4). Preservice teachers are asked to "draw a picture of yourself as a science teacher at work" (Thomas, Pedersen, \& Finson, 2001). Validation of the instrument was completed by Thomas et al. (2001).

\section{FINDINGS}

The findings revealed that preservice teachers conceptualized their role as a science educator differently before and after taking a science methods course. Data from eighty preservice teachers over the course of two years revealed that 72 of the 80 students' perceptions changed when asked what a science teacher "looks like" in the classroom. Teacher position, actions of the teacher, environment of the classroom setting and a written description reveal that perceptions changed over the 16 weeks each semester. Table 2 illustrates the pre/post students' illustrations and their perceptional changes from year one to year four.

Table 2

Descriptive Statistics for DASTT-C Pretest, Posttest, and differences

\begin{tabular}{lllllll}
\hline Group & & Pretest (\%) & \multicolumn{5}{c}{ Posttest (\%) } \\
\hline & $\mathrm{N}$ & $\mathrm{M}$ & $\mathrm{SD}$ & $\mathrm{M}$ & $\mathrm{SD}$ & $\Delta$ \\
\hline Year 1 & 20 & 2.02 & 0.512 & 2.90 & 0.248 & 0.88 \\
Year 2 & 20 & 1.90 & 0.507 & 2.6 & 0.248 & 0.70 \\
Year 3 & 20 & 2.01 & 0.558 & 2.88 & 0.274 & 0.87 \\
Year 4 & 20 & 2.06 & 0.584 & 2.75 & 0.040 & 0.70 \\
\hline Nor
\end{tabular}

Note: $* p<.05$.

Each year students began the semester with a teacher-focused perception of what it meant to be a science teacher, yet over the course of 16 weeks, reported their perceptions of what it meant to be a teacher of science changed. Year one saw the largest change in students' depiction of what it meant to be a teacher of inquiry-based 
science instruction followed by year three. Years one and four were equal in their perceptual changes.

Each year students began the semester with a teacher-focused perception of what it meant to be a science teacher, yet over the course of 16 weeks, reported their perceptions of what it means to be a teacher of science changed. That is, the self-image of themselves as teachers of science shifted in a short period of time. Go and Kang (2015) have demonstrated it is possible to shift individual's self-image paradigms from one of traditional teaching of science to a more constructivist approach. It is easier to do before teachers become entrenched in their own teaching methods, and hold mental maps of teaching that are less likely to be changed. Therefore, it's important to reach pre-service teachers. It is important to examine beliefs about how to teach science, as beliefs influence science teaching behaviors (Markic \& Eilks, 2008), inform the roles of teachers and learners in science education, and provide a foundation for developing materials (Sadhana, et al., 2012; Thomas, Pederson, Finson, 2001). Moreover, with a teacher-centered approach to teaching science, preservice teachers were more easily influenced to change their perceptions of what it means to be a teacher of science. It is through modeling in a college classroom that this task can be easily accomplished.

\section{Reflective Analysis}

The shifts in teachers' self-concept is apparent in the numerical data, but the shifts in attitudes is also seemingly important to note. Through the analysis of the preservice teachers' reflection, three themes became apparent, which include: teacher as facilitator, students as teachers, learning through inquiry. Through the examination of the reflective piece of students' drawings codes were developed that helped create the three themes or categories described.

\section{Theme 1: Teacher as facilitator.}

The first theme, teacher as facilitator, was referenced a total of 53 times in the 80 reflective drawings. Words such as facilitator, organizer, not a typical teacher, leader, and other terms to describe the teacher as one that helped and supported and not the sage at the front of the room. Specifically, student 23 stated, "The day of the teacher knowing everything about everything is gone. We need to help students understand and question. I can do this by knowing the content, but also by knowing how to question students to help them think beyond what is in front of them." Moreover, student 57 stated, "Teaching science is much different today than when I learned. I always thought teachers knew everything. Now, we have to know how to teach not so much what to teach."

These two examples help illustrate the idea of inquiry-based instruction and the shift of science education to a Social Cognitive Theory lens of teaching.

\section{Theme 2: Students as teachers.}

The theme, students as teachers, was referred to 37 times in the reflective piece of the illustrations. Closely related to the teacher as the facilitator, this idea of the students taking on the teaching role in the classroom was evident. Students referred to as students taking the lead in both instructing and learning while engaging in inquiry-based science 
lessons and experiments. Student 24 stated, "At the beginning of the semester, I thought that the only teacher was the one in front of the room. Everyone is a teacher in an inquiry-based classroom." These sentiments were found throughout many of the reflections. More specifically, Student 12 posit, "I can clearly see that students are teachers and teachers are students in many cases. It is important to make this shift in your mind as a beginning teacher." Peer learning is at the center of Bandura's Social Learning Theory (Bandura, 1977). The collaborative and cooperative learning that occurs allows for learning to take place from learners in many ways (Bond, Cohen, \& Sampson,2001). "Engaging students as teachers and evaluators in the learning process is a particularly effective form of partnership" (Healey, Flint, \& Harrington, 2014, p.8).

\section{Theme 3: Learning through inquiry}

The third and final theme, learning through inquiry, was prevalent throughout the qualitative component of the data. Grounded in Dewey's model of inquiry, science education is the quintessential example of formulating problems and finding solutions grounded in reflective learning. Many students referred to an understanding, after instruction, that learning occurs more often and at a deeper level when a teacher utilizes an inquiry approach to teaching and learning. Students referred to learning through inquiry 28 times. Specifically, Student 13 stated, "I guess I learned science through inquiry methods as a kid, but I don't remember. It just makes sense to allow students to figure out the answers by working together and the teacher learning instead of telling students the answers." Likewise, Student 21 said, "learning the way scientists work and learn is effective for students. I also think it provokes critical thinking and problem solving."

Inquiry-based learning emphasizes learners finding answers to their questions (Gibson \& Chase, 2002), and this type of teaching promotes meaningful and depth of knowledge (Apedoe, 2007). Roth (1998) posits that many undergraduate programs do not promote inquiry-based instructional strategies in science methods courses thus many graduates do not utilize this type of instruction in their classrooms. This lack of exposure then perpetuates the cycle of lack of knowledge and experience.

\section{IMPLICATIONS}

As noted earlier, the teaching of science, especially at the elementary level, has often taken a back seat to the teaching of reading and language arts, mathematics, and social studies. There are many reasons for this occurrence, among them, teacher accountability that is tied to student performance on state assessments, specifically in reading and math, but it can be argued, that even more so, early childhood educators generally lack a sense of self-confidence in the area of science education. Again, hearkening back to the old adage that "teachers teach as they were taught," it is still very common to find teachers, both veteran and novice alike, clinging to the traditionalist mode of teaching science. They cling to this security blanket of teaching science facts, and directing, if not totally performing, science experiments, in an effort to control the entire process of science instruction. As generalists, early childhood educators, often regard themselves as weak in the area of science, hence, the conservative approach to science instruction. 
Meanwhile, with the teacher education community at large and, more specifically, the science teacher education community acknowledging and embracing the concepts of actively engaged learners, discovery and/or inquiry-based learning, as well as the power of reflection and incorporating reflective practices into daily instruction, the move has been well underway since the turn of the century, shifting classroom roles to teacher as facilitator, and students as teachers, leading to learning through inquiry. With that said, the results of this study indicate the importance of teacher preparation programs and the responsibility they have to model exemplary teaching practices, actively engaging learners by implementing inquiry-based learning and employing reflective practices. By doing so, teacher preparation programs can have a positive impact on preservice teacher self-efficacy, which translates to improved preservice teachers' Personal Teaching Efficacy (PTE) and General Teaching Efficacy (GTE). Further, these exemplary practices should be incorporated not only within science methods courses, but across disciplines, throughout the progression of teacher preparation courses.

\section{CONCLUSION}

In conclusion, it was determined that when preservice teachers are engaged in an undergraduate science methods course that emphasizes inquiry-based instructional strategies students become aware of the importance of this type of instruction. Moreover, perceptions changed over the course of 16 weeks and their teaching selfefficacy increased after exposure to inquiry-based teaching and learning strategies. Through active collaboration and participation, preservice teachers were able to see the value in this type of instruction. By learning in ways that their future students will learn, preservice teachers came to understand that engagement with content through discussions, experiments, and other inquiry-based strategies not only improved their ability to teach but their ability to understand and take ownership of scientific concepts.

\section{REFERENCES}

Apendoe, X. S. (2007). Engaging students in inquiry: Tales from an undergraduate geology laboratory-based course. Science Education, 92, 631-663.

Bandura, A. (1977). Toward a unifying theory of behavioral change. Psychological Review, 84, 191-215.

Bandura, A., (1986). Social foundations of thought and action: A social cognitive theory. Englewood Cliffs, NJ: Prentice-Hall.

Bandura, A. (1997). Self-efficacy: The exercise of control. New York: Freeman.

Bullock, S., Sator, A., (2015). Maker pedagogy and science teacher education. Journal of the Canadian Association for Curriculum Studies, 13(1), 60-87.

Baxter, P., \& Jack, S. (2008). Qualitative case study methodology: Study design and implementation for novice researchers. The Qualitative Report, 13(4), 544-559.

Boud, D., Cohen, R., \& Sampson, J. (2001). Peer learning in higher education: Learning from and with each other. London: Kogan Press. 
Cantrell, P., Young, S., and Moore, A., (2003). Factors affecting science teaching efficacy of preservice teachers. Journal of Science Teacher Education, 14, 177-192.

Damnjanovic, A., (1999). Attitudes toward inquiry-based teaching: Differences between preservice and in-service teachers. School Science and Mathematics, 99(2), 71-76.

Dougherty, D. (2013). The maker mindset. In M. Honey \& D.E. Kanter (Eds.), Design, make, play: Growing the next generation of STEM innovators (pp. 7-11). New York, NY: Routledge.

Gibson, H.L., Chase, C. (2002). Longitudinal impact of an inquiry-based science program on middle school students' attitudes toward science. Science Education, 86, 693-705.

Gibson, S. \& Dembo, M. H. (1984). Teacher efficacy: A construct validation. Journal of Educational Psychology, 76(4), 569 - 582.

Grierson, A., (2010). Changing conceptions of effective teacher education: The journey of a novice teacher educator. Studying Teacher Education, 6(1), 3-15.

Go, Y. \& Kang, J. (2015). Early childhood pre-service teachers' self-images of science teaching in constructivism science education courses. Asia-Pacific Forum on Science Learning and Teaching, 16(2).1-25.

Healey, M., Flint, A., \& Harrington, K. (2014). Engagement through partnership: Students as partners in learning and teaching in higher education. Retrieved from https://www.neaacademcy.ad.uk/systemfiles/resouces/engagement_through_partnership.pdf.

Kim, H.K. (2011). Developmentally Appropriate Practice (DAP) as Defined and Interpreted by Early Childhood Preservice Teachers: Beliefs About DAP and Influences of Teacher Education and Field Experience. SRATE Journal, 20(2), 12-22.

Manz, E., (2015). Resistance and the development of scientific practice: Designing the mangle into science instruction. Cognition and Instruction, 33(2), 89-124.

Markic, S., \& Eilks, I. (2008). A case study on German first year chemistry, student teachers' beliefs about chemistry teaching, and their comparison with student teachers from other science teaching domains. Chemistry Education Research and Practice, 8, 25-34.

Melville, W., Fazio, X., Bartley, A., Jones, D., (2008). Experience and reflection: Preservice science teachers' capacity for teaching inquiry. Journal of Science Teacher Education. 19(5), 477- 494.

Meyer, D., (2012). Designing design challenges: Getting the details right. Using engineering problems to enact inquiry learning. The Science Teacher, 79(2), 58-62.

Moore, J., (1993). Science as a way of knowing. Cambridge, MA: Harvard University Press.

Myers, J., (2012). Lesson study as a means for facilitating preservice teacher reflectivity. International Journal for the Scholarship of Teaching and Learning, 6(1), $1-21$. 
National Research Council.(1996). National Science Education Standards. Washington, D.C.: National Academy Press.

Pajares, M., (1992). Teachers' beliefs and educational research: Cleaning up a messy construct. Review of Educational Research, 62(3), 307-332.

Peppler, K., \& Bender, S. (2013). Maker movement spreads innovation one project at a time. Kappan, 95(3), 22-27.

Roth, W. M. (1998). How prepared are preservice teachers to teach scientific inquiry? Levels of performance in scientific representations practices. Journal of Science Teacher Education, 9, 25-48.

Sadhana, P., Stylianou, A., \& Goldstien, J. (2012). Comparing classroom enactiments of an inquiry curriculum: Lessons learned from two teachers. The Journal of the Learning Science, 16(1), 81-130.

Senge, P., (1990). The fifth discipline, the art and practice of the learning organization, New York, NY: Doubleday.

Senge, P., Kleiner, A., Roberts, A., Ross, R., Smith, B. (1994). The fifth discipline fieldbook. New York, NY: Doubleday.

Smith, K.E. (1997). Student teachers' beliefs about developmentally appropriate practice: pattern, stability, and the influence of locus of control. Early Childhood Research Quaterly, 12(2), 221-243.

Smolleck, L., Morgan, A., (2011). Changes in preservice teachers' self-efficacy: From science methods to student teaching. Journal of Educational and Developmental Psychology, 1(1), 133-145.

Spector, B., Burkett, R., Leard, C., (2007). Mitigating resistance to teaching science through inquiry: Studying self. Journal of Science Teacher Education, 18, 185-208.

Swars, S., Smith, S., Smith, M., Hart, L., (2006). Elementary preservice teachers' changing pedagogical and efficacy beliefs during a developmental teacher preparation program. Psychology of Mathematics Education-North America, 2, 548-555.

Thomas, J. A, Pedersen, J. E., \& Finson, K. (2001) Validating the Draw -A-ScienceTeacher Checklist (DASTT-C): Exploring mental models and teacher beliefs. Journal of Science Teacher Education, 12(3), 295-310.

Tschannen-Moran, M., Woolfok, Hoy, A., \& Hoy, W. K. (1998). Teacher efficacy: Its meaning and measure. Review of Educational Research, 68(2), 202-248.

Yeotis, C., Bolick, M., French, D., Keig, P., Nason, P., Shroyer, G., et al. (1998) Preconference workshop: An exemplary elementary science methods course. Paper presented at the annual international meeting of the Association for the Education of Teachers in Science, Minneapolis, MN.

Yin, R. K. (2009). Case study research: Design and method (4th ed.). Thousand Oaks, CA: Sage. 